\title{
Comprehensive strontium isotope study of Quaternary volcanic rocks from the Izu-Ogasawara arc
}

\author{
KenJI Notsu, ${ }^{1}$ NAOKI IsshiKi ${ }^{2}$ and MASATAKa HiRANo ${ }^{1 *}$ \\ Institute of Chemistry, University of Tsukuba, Sakura-mura, Niihari-gun, Ibaraki 305, ${ }^{1}$ \\ and Geological Survey of Japan, Yatabe-machi, Tsukuba-gun, Ibaraki $305,{ }^{2}$ Japan
}

(Received June 2, 1983: Accepted September 26, 1983)

\begin{abstract}
In the Izu-Ogasawara arc, many Quaternary volcanoes are located in a line parallel to the Izu-Ogasawara Trench. ${ }^{87} \mathrm{Sr} /{ }^{86} \mathrm{Sr}$ ratios were determined for 65 samples of Quaternary volcanic rocks, 4 cognate inclusions and one sample of basement rock from 15 volcanic islands and 3 submarine volcanoes. In this arc, the ${ }^{87} \mathrm{Sr} /{ }^{86} \mathrm{Sr}$ ratios in several rocks from the same volcano agree with one another within 0.0002 , regardless of the difference of the rock types and the eruptive stages. The ratios of the volcanoes along the volcanic front in the Izu-Ogasawara arc were constant over $1,200 \mathrm{~km}$ and were all within the range between 0.7034 and 0.7039 , which is significantly lower than those from the Northeast Japan arc (0.7038-0.7044) (NOTSU, 1983). In the northern region of the Izu-Ogasawara arc, across-arc ${ }^{87} \mathrm{Sr} /{ }^{86} \mathrm{Sr}$ ratio variation was found. The ratios decrease with increasing depth of the Wadati-Benioff zone. Even in the volcanic rocks distant from the volcanic front, the ratios $(0.7033-0.7035)$ were slightly higher than those in normal-type MORB, so it is suggested that a small amount of oceanic sediment, altered basalt or sea water component that accompanies the subducting slab has been contributed to the source magma which originates from a partially melted, upper mantle wedge. This contribution becomes smaller with increasing distance from the volcanic front.
\end{abstract}

\section{INTRODUCTION}

The Izu-Ogasawara arc is located along the boundary of two oceanic plates, the Pacific plate and the Philippine Sea plate, parallel to. the Izu-Ogasawara Trench. This arc belongs to the circum-Pacific island arc system and is adjacent to the Norcheast Japan arc and the Mariana arc to the north and south, respectively.

Recently, NoTsu (1983) revealed the spatial distribution of the ${ }^{87} \mathrm{Sr} /{ }^{86} \mathrm{Sr}$ ratios in Quaternary volcanic rocks from the Northeast Japan arc, finding anomalously high ${ }^{87} \mathrm{Sr} /{ }^{86} \mathrm{Sr}$ ratio region at the triple junction of the Pacific, the Philippine Sea and the Eurasia plates. He confirmed the existence of the across-arc ${ }^{87} \mathrm{Sr} /{ }^{86} \mathrm{Sr}$ ratio variation in broader areas of the Northeast
Japan arc, which was first pointed out by HEDGE and KNIGHT(1969) from only one cross section $\left(40^{\circ} \mathrm{N}\right)$ of northeast Japan. NoTSU (1983) also clarified the fact that ${ }^{87} \mathrm{Sr} /{ }^{86} \mathrm{Sr}$ ratios of the Northeast Japan arc are higher than those of the Izu-Ogasawara arc, which had previously been reported by several authors (PUShKar, 1968, MATSUda et al., 1977, Kurasawa, 1979, Nohda and Wasserburg, 1981 and STERN, 1982). However, these published data are insufficient for the characterization of the Izu-Ogasawara arc, because the ${ }^{87} \mathrm{Sr} /{ }^{86} \mathrm{Sr}$ ratios were measured for small numbers of the volcanic rocks of a few volcanic islands. Furthermore, uncertainties associated with the ${ }^{87} \mathrm{Sr} /{ }^{86} \mathrm{Sr}$ analyses of earlier studies were too large to discuss the fine structure in the ${ }^{87} \mathrm{Sr} /{ }^{86} \mathrm{Sr}$ ratio variations. Therefore,

*Present address: Central Research Laboratory, Sumitomo Metal Mining Company Ltd., 3-18-5, Nakakokubun, Ichikawa, Chiba 272, Japan. 


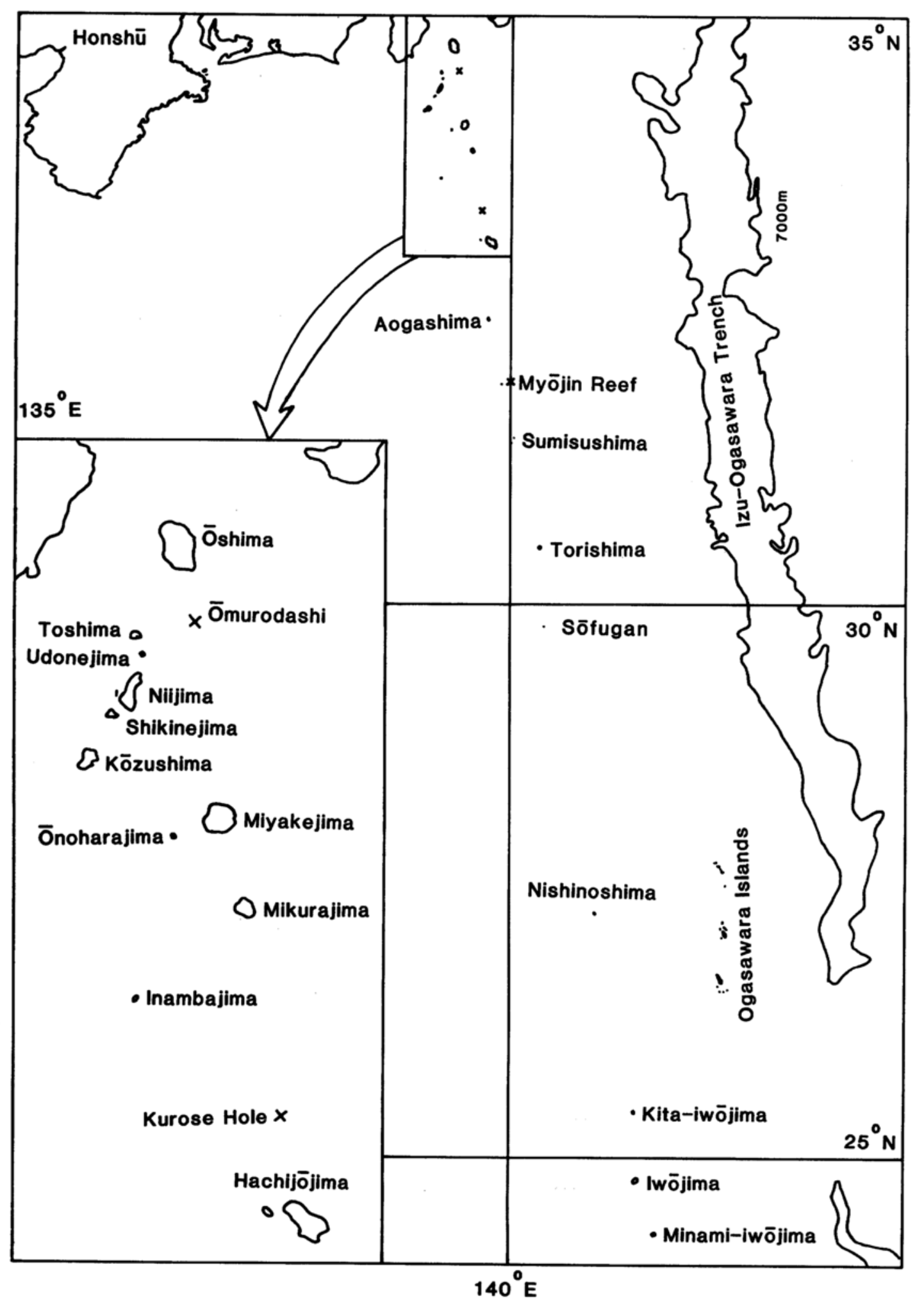

Fig. 1. Locality map of the Izu-Ogasawara arc. 
it is very important to obtain a set of coherent data for the study of the ${ }^{87} \mathrm{Sr} /{ }^{86} \mathrm{Sr}$ ratio variation in the Izu-Ogasawara arc.

The purpose of this work is to make clear the spatial distribution of the ${ }^{87} \mathrm{Sr} /{ }^{86} \mathrm{Sr}$ ratios in the Izu-Ogasawara arc, and to aid the characterization of island arcs using comprehensive strontium isotope data. We will also discuss the relationship between the ${ }^{87} \mathrm{Sr} /{ }^{86} \mathrm{Sr}$ ratios of arc volcanic rocks and the subduction structure in view of the comparison between the Izu-Ogasawara and Northeast Japan arcs.

\section{SAMPLeS}

Figure 1 shows the geographical setting of this study. 61 samples of Quaternary volcanic rocks, 4 samples of cognate inclusions in some of these rocks and one sample of basement rock were selected from 15 volcanic islands. We also analyzed 3 volcanic rock samples dredged from 2 submarine volcanoes, Ōmurodashi (HAMURo et al., 1983) and Kurose Hole (Honza et al., 1981), and one pumice sample ejected by the submarine eruption of Myōjin Reef (Suwa, 1953). The localities and the references of these 70 samples analyzed in this study are summarized in the Appendix.

Most of these samples were collected by one of the authors (N.I.). Donated samples are those from Ōmurodashi, Inambajima, Kurose Hole, Nishinoshima, Myōjin Reef and Minami-iwōjima.

Table 1. Analytical results

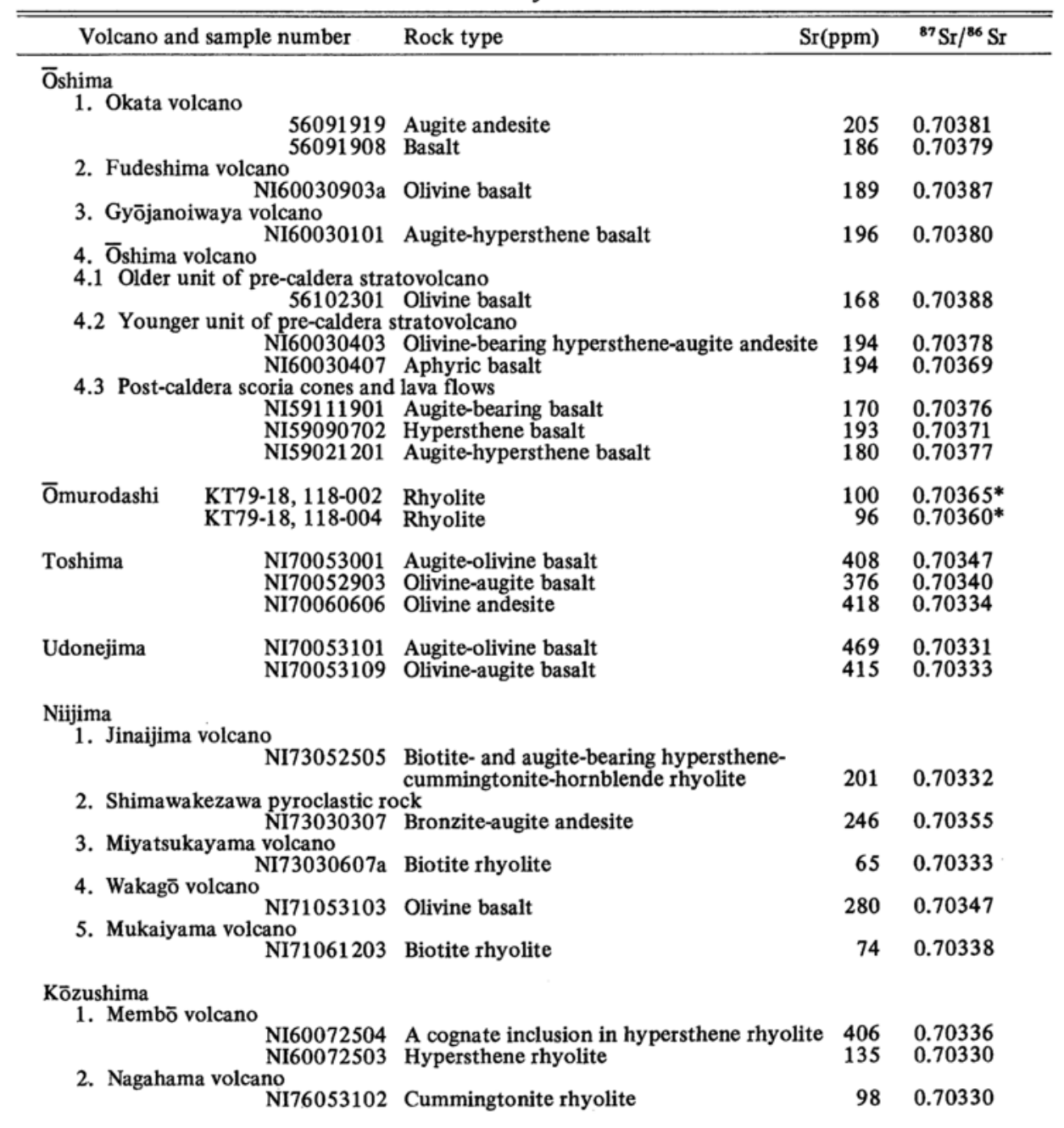


3. Sanukayama volcano

4. Tenjōsan volcano

NI60072102 Rhyolite

60

40

NI60072406 Biotite rhyolite
0.70333

0.70340

0.70351

0.70356

0.70352

0.70369

0.70343

0.70346

Ōnoharajima

NI57080611b Hypersthene-augite-olivine basalt NI62090902 Hypersthene- and olivine-bearing augite

NI57072505 A cognate inclusion in augite-hypersthene andesite (NI57072504)

Mikurajima

1. Main stratovolcano

2. Lava dome group

0.70358

Augite-olivine basalt

NI60091805 Olivine-augite-hypersthene andesite 264

0.70350

Inambajima

NI62060801c Augite-hypersthene andesite

Kurose Hole

GH79-4-RC63 Hypersthene-bearing hornblende dacite

Hachijojima

1. Basement rock

2. Yokomagaura volcano

NI55071806 Olivine-hypersthene-augite gabbro 186

NOH02 Ferrohypersthene-ferropigeonite-ferroaugite andesite

3. Higashiyama volcano

3.1 Pre-caldera stratovolcano

$\begin{array}{rlrr}\text { NI54071401 } & \text { Aphyric basalt } & 151 & 0.70363 \\ \text { NI54072007 } & \text { Aphyric andesite } & 145 & 0.70370 \\ \text { NI52101709 } & \text { Aphyric andesite } & 196 & 0.70373 \\ \text { NI57032205(2) } & \text { Ferroaugite-ferrohortonolite quartz andesite } & 131 & 0.70367 \\ \text { NI53011301 } & \text { Ferroaugite-fayalite quartz dacite } & 140 & 0.70363\end{array}$

3.2 Post-caldera stratovolcano

NI52101202 Augite-hypersthene andesite

NI54071706 Augite-hypersthene-olivine basalt

NI54073103 Olivine-hypersthene-augite andesite

NI52092601 Augite-olivine basalt 144

NI54071101 Aphyric basalt 165

4. Nishiyama volcano

NI55072003 Coarse-grained basalt

NI53072705 Iron-rich basalt 168

0.70363

0.70362

0.70368

0.70364

0.70366

Aogashima

NI53081111 Olivine basalt

0.70364

NI53081102 Aphyric basalt

0.70359

NI53081105 Augite andesite

Myōjin Reef

Pumice Augite-hypersthene dacite

Torishima

NI56101805 Augite-olivine basalt

NI56101509 Hypersthene-augite andesite

NI56102108 Hypersthene-bearing augite-olivine basalt

NI56102003 Hypersthene-bearing augite-olivine basalt

NI56102103 Aphyric basalt

$182 * *$

NI56102102 A cognate inclusion in aphyric basalt

$168 * *$ andesite

Nishinoshima

NI74071802 Augite-hypersthene andesite

$235 * * \quad 0.70349$

B Two pyroxene andesite

Iwōjima

NI68082304 Augite-olivine trachyandesite or benmoreitic

$\begin{array}{rlr} & \text { trachyte } & 459 * * \\ \text { NI68082301b } & \text { Cognate syenite inclusion } & 561 * * \\ \text { N168082503 } & \text { Augite-olivine trachyandesite or benmoreitic }\end{array}$

N168082503 Augite-olivine trachyandesite or benmoreitic trachyte 285**

0.70364

0.70360

0.70364

Minami-iwōjima

79043001 Augite-olivine basalt

0.70374 79043002 Augite-olivine basalt

* Residues after hot HCl leaching are analyzed.

** Determined by WD-XRF. All others by ED-XRF. 
In some volcanic islands, we selected several samples, taking the rock type and sequence of eruption into consideration to check the homogeneity of the ${ }^{87} \mathrm{Sr} /{ }^{86} \mathrm{Sr}$ ratios in a given volcanic island. One sample of basement plutonic rock was analyzed for Hachijōjima island. We also measured the ${ }^{87} \mathrm{Sr} /{ }^{86} \mathrm{Sr}$ ratios in 4 samples of cognate inclusions in the Quaternary volcanic rocks from 4 islands, Kōzushima, Ōnoharajima, Torishima and Iwōjima.

\section{EXPERIMENTAL and RESULTS}

Analytical procedures for the determination of strontium isotope composition and elemental concentration were reported by NoTSU (1983). Experimental results are shown in Table 1. Any superficial sea water contamination was removed by leaching the sample with hot $6 \mathrm{~N} \mathrm{HCl}$ solution. The strontium concentrations of the 58 rock samples were determined by WD (wave length dispersive)-XRF method and of other 12 samples by ED (energy dispersive)XRF method.

In the strontium isotope analysis, reproducibility of ${ }^{87} \mathrm{Sr} /{ }^{86} \mathrm{Sr}$ ratios of the same sample is less than 0.00005 and the values of NBS 987 standard sample were measured in the range from 0.71028 to 0.71033 during this work. The reproducibility of strontium analysis is less than 5 and $10 \%$ for WD-XRF and ED-XRF methods, respectively.

\section{Discussions}

Variation of ${ }^{87} \mathrm{Sr} /{ }^{86} \mathrm{Sr}$ ratios in the same volcano The mean values and the ranges of the ${ }^{87} \mathrm{Sr} /{ }^{86} \mathrm{Sr}$ ratios in all volcanic islands studied are summarized in Table 2 . It is evident that the ${ }^{87} \mathrm{Sr} /{ }^{86} \mathrm{Sr}$ ratios in various rocks from the same volcano agree with one another within 0.0002 .

In order to understand the precise variation of ${ }^{87} \mathrm{Sr} /{ }^{86} \mathrm{Sr}$ ratios in the same volcano, the ratios are plotted against $\mathrm{SiO}_{2}$ contents (refer to Appendix) for $\bar{O}$ shima and Hachijōjima volcanic islands in Fig. 2. According to IssHIKI
Table 2. Summary of the ${ }^{87} \mathrm{Sr} /{ }^{86} \mathrm{Sr}$ ratios in the Izu-Ogasawara arc

\begin{tabular}{lccc}
\hline Volcanic island & $\begin{array}{c}\text { Number of } \\
\text { samples }\end{array}$ & Mean & Range \\
\hline Oshima & 10 & 0.70379 & $0.70369-0.70388$ \\
Omurodashi & 2 & 0.70363 & $0.70360-0.70365$ \\
Toshima & 3 & 0.70340 & $0.70334-0.70347$ \\
Udonejima & 2 & 0.70332 & $0.70331-0.70333$ \\
Niijima & 5 & 0.70341 & $0.70332-0.70355$ \\
Kōzushima & $5^{* *}$ & 0.70334 & $0.70330-0.70340$ \\
Miyakejima & 4 & 0.70357 & $0.70351-0.70369$ \\
Onoharajima & $2^{* *}$ & 0.70345 & $0.70343-0.70346$ \\
Mikurajima & 3 & 0.70355 & $0.70350-0.70358$ \\
Inambajima & 1 & 0.70349 & - \\
Kurose Hole & 1 & 0.70343 & - \\
Hachijōjima & $14 *$ & 0.70365 & $0.70358-0.70373$ \\
Aogashima & 3 & 0.70352 & $0.70345-0.70359$ \\
Myōjin Reef & 1 & 0.70344 & - \\
Torishima & $7^{* *}$ & 0.70353 & $0.70350-0.70357$ \\
Nishinoshima & 2 & 0.70346 & $0.70343-0.70349$ \\
Iwōjima & $3^{* *}$ & 0.70363 & $0.70360-0.70364$ \\
Minami-iwōjima & 2 & 0.70376 & $0.70374-0.70378$ \\
\hline
\end{tabular}

* Including basement rock.

**Including cognate inclusions.
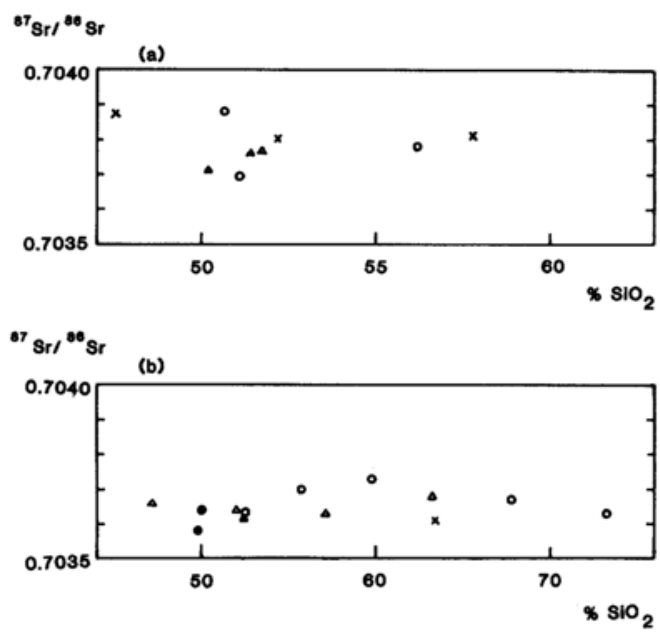

Fig. $2 .{ }^{87} \mathrm{Sr} /{ }^{86} \mathrm{Sr}$ ratio variation against the $\mathrm{SiO}_{2}$ content.

(a)Oshima $\times$ Okata, Fudeshima and Gyōjanoiwaya volcanoes

- Oshima volcano (pre-caldera stage)

$\triangle$ Oshima volcano (post-caldera stage)

(b) Hachijōjima $\times$ Yokomagaura volcano

- Higashiyama volcano (pre-caldera stage)

$\triangle$ Higashiyama volcano (post-caldera stage)

- Nishiyama volcano 
(1964), Ōshima volcano was born in late Pleistocene on the older basement volcanoes, such as Okata, Fudeshima and Gyōjanoiwaya volcanoes, which were formed in some period from late Pliocene to Pleistocene. The volcanic acitivity of the Ōshima volcano proceeded from the pre-caldera stage to the post-caldera stage. We cannot distinguish the ${ }^{87} \mathrm{Sr} /{ }^{86} \mathrm{Sr}$ ratios of the older volcanoes, the pre-caldera and the post-caldera stages of $\bar{O}$ shima volcano in Fig. 2(a) from one another, taking analytical uncertainties of the ${ }^{87} \mathrm{Sr} /{ }^{86} \mathrm{Sr}$ ratios into consideration. This means that the ${ }^{87} \mathrm{Sr} /{ }^{86} \mathrm{Sr}$ ratios in the magma of $\bar{O}$ shima volcanic island have been similar since the late Pliocene. Figure 2(a) also shows that the ${ }^{87} \mathrm{Sr} /{ }^{86} \mathrm{Sr}$ ratios are constant irrespective of the $\mathrm{SiO}_{2}$ content. In the case of Hachijōjima, older volcanoes (for example, Yokomagaura volcano), Higashiyama volcano and Nishiyama volcano were formed in this order (IssHIKI, 1959, 1963). Figure 2(b) also shows neither systematic ${ }^{87} \mathrm{Sr} /{ }^{86} \mathrm{Sr}$ ratio variation with time nor that with $\mathrm{SiO}_{2}$ content. It must be mentioned that the gabbro block which might have been derived from Tertiary basement has a ${ }^{87} \mathrm{Sr} /{ }^{86} \mathrm{Sr}$ ratio identical with that of other Quaternary volcanic rocks (see Table 1).

In the Izu-Ogasawara arc, rhyolite forms Niijima, Shikinejima, Kōzushima and at least a part of Ōmurodashi Bank (HAmuro et al., 1983). In Niijima, small quantities of basalt and andesite occur together with rhyolite and their ${ }^{87} \mathrm{Sr} /{ }^{86} \mathrm{Sr}$ ratios are all identical. If the rhyolites are formed by remelting of a thin crust (IsshiKI et al., 1982), this crust must have the ${ }^{87} \mathrm{Sr} /{ }^{86} \mathrm{Sr}$ ratios similar to those of basalts and andesites which are considered to have been derived from mantle by subduction-related magma genesis.

Four samples of cognate inclusions in volcanic rocks were analyzed. They are the inclusions in rhyolite (Kōzushima), in andesite (Ōnoharajima), in basalt (Torishima) and in trachyandesite (Iwōjima). In all cases, ${ }^{87} \mathrm{Sr} /$ ${ }^{86} \mathrm{Sr}$ ratios of cognate inclusions and their host rocks were identical within 0.00005 , which is the same as the value of analytical uncertainty in this work.

Along-arc ${ }^{87} \mathrm{Sr} /{ }^{86} \mathrm{Sr}$ ratio variation In each volcanic island, ${ }^{87} \mathrm{Sr} /{ }^{86} \mathrm{Sr}$ ratios of various volcanic rocks are almost constant, regardless of the differences of the chemical composition and of the eruptive stage, as described in the previous section. Therefore, the ${ }^{87} \mathrm{Sr} /{ }^{86} \mathrm{Sr}$ ratio of one volcanic island can be represented as one mean value (Table 2). Figure 3 shows the spatial distribution of the ${ }^{87} \mathrm{Sr} /{ }^{86} \mathrm{Sr}$ ratios of the volcanic islands in the Izu-Ogasawara arc. In this figure, ${ }^{87} \mathrm{Sr} /{ }^{86} \mathrm{Sr}$ ratios are arbitrarily classified into three groups, 0.7033-0.7035, $0.7035-0.7037$ and $0.7037-0.7039$.

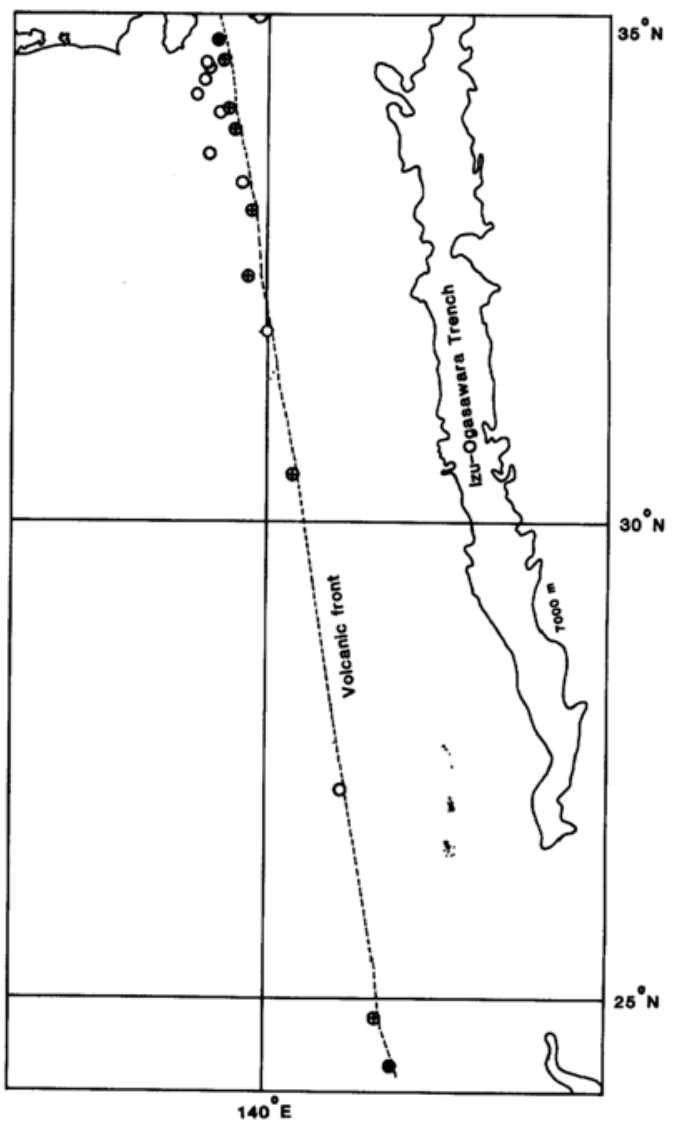

Fig. 3. Spatial distribution of ${ }^{87} \mathrm{Sr} /{ }^{86} \mathrm{Sr}$ ratios in Quaternary volcanic rocks of the Izu-Ogasawara arc.
○ $0.7033-0.7035$
- $0.7037-0.7039$ 


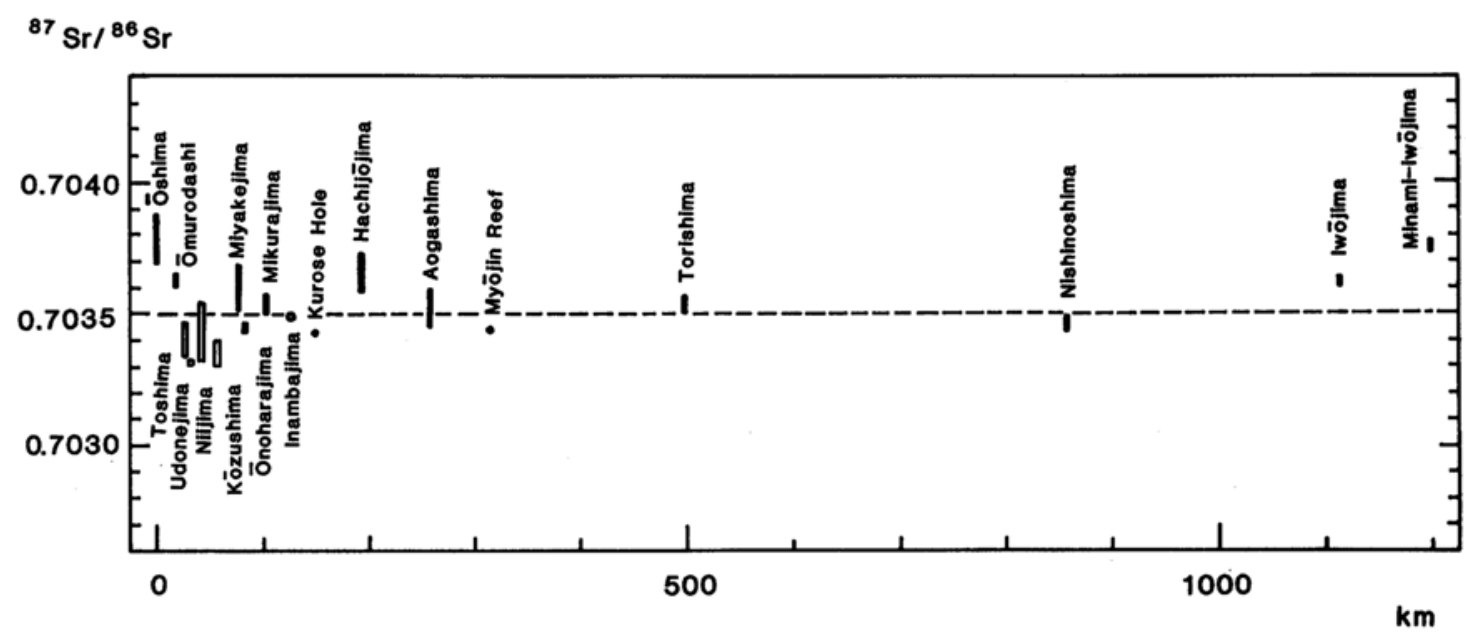

Northward

Southward

Fig. 4. Variation of ${ }^{87} \mathrm{Sr} /{ }^{86} \mathrm{Sr}$ ratios in the along-arc direction.

Volcanoes on the volcanic front

एVolcanoes behind the volcanic front

Figure 4 demonstrates the along-arc ${ }^{87} \mathrm{Sr} /$ ${ }^{86} \mathrm{Sr}$ ratio variation in the Izu-Ogasawara arc. In this figure, the horizontal scale is denoted as the distance from Öshima. It is very surprising that the volcanic rocks occurring on the volcanic front of the Izu-Ogasawara arc have uniform ${ }^{87} \mathrm{Sr} /{ }^{86} \mathrm{Sr}$ ratios from 0.7034 to 0.7039 over $1,200 \mathrm{~km}$, without exception. This suggests that the magma genesis processes and source components are very similar in the whole region of the Izu-Ogasawara arc. The uniformity of the ${ }^{87} \mathrm{Sr} /{ }^{86} \mathrm{Sr}$ ratios of the volcanoes on the volcanic front in the IzuOgasawara arc is found to expand southward to the Mariana arc (MEIJER, 1976, DixoN and BAtizA, 1979 and STERN, 1982). The volcanoes in the Fuji, Hakone and Izu region of Honshū also have ${ }^{87} \mathrm{Sr} /{ }^{86} \mathrm{Sr}$ ratios similar to those in the Izu-Ogasawara arc (KURASAwA, 1979).

Within the group of uniform ${ }^{87} \mathrm{Sr} /{ }^{86} \mathrm{Sr}$ ratios in the range, 0.7034 to 0.7039 , however, there seems to be minute variation. The ratios tend to decrease from $\bar{O}$ shima to the southward and are nearly constant between Mikurajima and Nishinoshima except for slightly higher ratios in Hachijojima. The ratios increase from Nishinoshima to Minami-iwōjima. This trend of minute ${ }^{87} \mathrm{Sr} /{ }^{86} \mathrm{Sr}$ ratio variation may be due to small differences in magma genesis, or to changes in the mode of subduction of the Pacific plate. Otherwise, this variation may be caused by mantle heterogeneity. Hirano (1982) and Hirano et al. (1982) pointed out that the degree of partial melting of the mantle wedge changed in the along-arc direction. The degrees of the partial melting in Oshima and Hachijōima are identical and distinctly higher than in Miyakejima or Mikurajima. As the order of the ${ }^{87} \mathrm{Sr} /{ }^{86} \mathrm{Sr}$ ratios of these islands is $\overline{\text { Orhima }}>$ Hachijojima $\geqq$ Miyakejima $\fallingdotseq$ Mikurajima, a correlation between the strontium isotope composition and the degree of partial melting is roughly observed. In order to make sure of this correlation, it is necessary to determine the degree of the partial melting for the volcanoes to the south of Hachijojima.

In the Izu-Ogasawara arc, the rock type changes along the volcanic front. Rocks of the low-alkali tholeiite series are dominant in the northern half of this arc, but rocks of highalkali tholeiite series (Nishinoshima), of alkali 
rock series (Iwōjima) and of intermediate composition between high-alkali tholeiite and alkali rock series (Minami-iwōjima) occur in the southern half. Although there seems fine variation in the ${ }^{87} \mathrm{Sr} /{ }^{86} \mathrm{Sr}$ ratios in these rocks, it should be pointed out that the ${ }^{87} \mathrm{Sr} /{ }^{86} \mathrm{Sr}$ ratios of trachyandesite and syenite are almost identical with those of the rocks of the lowalkali tholeiite series in the northern half. This may imply that the source materials of these alkali rocks are similar to those of the lowalkali tholeiitic rocks in this arc.

Across-arc ${ }^{87} \mathrm{Sr} /{ }^{86} \mathrm{Sr}$ ratio variation From Figs. 3 and 4 , across-arc ${ }^{87} \mathrm{Sr} /{ }^{86} \mathrm{Sr}$ ratio variation is observed in the northern region of the Izu-Ogasawara arc. The ratios decrease from the volcanic front to the back-arc side. The trends of decrease in ${ }^{87} \mathrm{Sr} /{ }^{86} \mathrm{Sr}$ ratios away from the volcanic front were also reported in the Scotia arc (HAWKESWORTH et al., 1977), the Mariana arc (MEIJER, 1976 and STERN, 1982) and the Northeast Japan arc (NoTsu, 1983). In the Sunda arc, however, ${ }^{87} \mathrm{Sr} /{ }^{86} \mathrm{Sr}$ ratios increase in the same direction (WHITFORD, 1975).

In the Izu-Ogasawara arc, other across-arc geochemical variations have been already reported. REE pattern of high-alumina basalt from Niijima (back-arc side) shows a nearly flat pattern, while tholeiitic basalts from $\bar{O}$ shima and Hachijojima (volcanic front side) have convex upward REE patterns (MASUDA, 1968 and Fujimaki and Kurasawa, 1980). Recent results of $\mathrm{Sr} / \mathrm{Ca}-\mathrm{Ba} / \mathrm{Ca}$ systematics showed that the fractional crystallization of the magma in Toshima, Udonejima and Kōzushima (backarc side) started with higher values of both $\mathrm{Sr}$ / $\mathrm{Ca}$ and $\mathrm{Ba} / \mathrm{Ca}$ ratios than that in $\bar{O}$ shima (volcanic front side), suggesting the degree of partial melting of the mantle material is smaller in the former volcanoes (ONUMA et al., 1981, 1983 and IssHIKI et al., 1982).

Even in the volcanic rocks away from the volcanic front in the Izu-Ogasawara arc, the ${ }^{87} \mathrm{Sr} /{ }^{86} \mathrm{Sr}$ ratios are slightly higher than those in the normal-type MORB (SUN et al., 1979), like the case of the Northeast Japan arc (NoTSU, 1983). Therefore, in the case of the volcanoes in island arcs, the primary magma with the ${ }^{87} \mathrm{Sr} /$ ${ }^{86} \mathrm{Sr}$ ratios of the mantle material may have been contaminated with a small amount of other materials with higher ${ }^{87} \mathrm{Sr} /{ }^{86} \mathrm{Sr}$ ratios. It seems reasonable that the source material is originated from the mantle wedge, because the ${ }^{18} 0 /{ }^{16} 0$ ratios in volcanic rocks from Hachijojima and $\bar{O}$ shima are 5.66-6.65 and 5.31-5.93\% (SMOW), respectively (MATSUHISA, 1979), which are identical with those in the mantle-derived rocks (TAYLOR, 1980). The $\mathrm{Sr} / \mathrm{Ca}-\mathrm{Ba} / \mathrm{Ca}$ systematics also supports the hypothesis that the source material of arc volcanic rocks are derived from the mantle, because the most primitive or the least fractionated basalts from each volcano occupy on a partial melting line of the mantle material with chondrite-like composition (ONuma et al., 1983). The REE patterns of volcanic rocks from Ōshima and Hachijōjima resemble those of MORB (MASUDA, 1968 and FUJIMAKI and KURASAWA, 1980), suggesting that the primary magma is derived from the mantle.

In order to explain the across-arc ${ }^{87} \mathrm{Sr} /{ }^{86} \mathrm{Sr}$ ratio variation, NOTSU (1983) suggested that the most likely candidate for the contaminant of the partially melted mantle material in the Northeast Japan arc is oceanic sediment associated with the subducting slab. In the case of the Izu-Ogasawara arc, oceanic sediments are also thought to have played an important role in the elevation of the ${ }^{87} \mathrm{Sr} /{ }^{86} \mathrm{Sr}$ ratios from MORB values in a manner analogous to the Northeast Japan arc. NoHDA and WASSERBURG (1981) also suggested the contribution of oceanic sediments to the partial melts in order to explain $\mathrm{Nd}-\mathrm{Sr}$ isotope systematics in 3 samples of the tholeiitic rocks from Öshima, Miyakejima and Hachijōjima. To explain our $\mathrm{Sr}$ isotope data, we cannot rule out the possibility that altered basalt or sea water components of the subducted slab enter the partial melts in the mantle wedge. At any rate, as the effect of contamination of oceanic sediments, altered basalt or sea water component does not clearly appear either in the 
major and trace element chemistry or in the ${ }^{18} 0 /{ }^{16} 0$ ratios of the primary magma formed from the partially melted mantle wedge, the amount of the contaminant must be very small. Furthermore, this contribution becomes smaller with increasing distance from the volcanic front.

Characterization of an individual arc by ${ }^{87} \mathrm{Sr} /{ }^{86} \mathrm{Sr}$ ratio NoTSU (1983) indicated that in the northern region of the Northeast Japan arc the ${ }^{87} \mathrm{Sr} /{ }^{86} \mathrm{Sr}$ ratios of several rocks from one volcano agreed with one another within 0.0003 and that the ratios of volcanic rocks on the volcanic front were almost constant $(0.7038$ 0.7045). In the case of the Izu-Ogasawara arc, the ${ }^{87} \mathrm{Sr} /{ }^{86} \mathrm{Sr}$ ratios in one volcano were found to scatter within 0.0002 and the range of the ratios along the volcanic front were 0.7034 to 0.7039 . The results indicate that an individual island arc has a specific ${ }^{87} \mathrm{Sr} /{ }^{86} \mathrm{Sr}$ ratio. We show the histograms of the ${ }^{87} \mathrm{Sr} /{ }^{86} \mathrm{Sr}$ ratios in the volcanic rocks from the Northeast Japan arc and from the Izu-Ogasawara arc in Fig. 5. In these histograms, the ${ }^{87} \mathrm{Sr} /{ }^{86} \mathrm{Sr}$ ratio of one volcano, which was estimated by averaging the several ratios in different samples from one volcano, corresponds to one frequency unit. The data of the Northeast Japan arc are calculated from Table 1 in NoTsu (1983). In this arc, the data of the southernmost region are excluded, because the region coincides with the triple junction of the plates. Figure 5 also shows the histogram of the ratios of the normal-type MORB, using the data in Fig. 8 in Sun et al., (1979).

Figure 5 characterizes the Northeast Japan arc and the Izu-Ogasawara arc on the basis of ${ }^{87} \mathrm{Sr} /{ }^{86} \mathrm{Sr}$ ratios, although the ranges of the ratios in the volcanic rocks on the back-arc side of both arcs overlap each other. The reason why the ${ }^{87} \mathrm{Sr} /{ }^{86} \mathrm{Sr}$ ratios in the volcanic rocks on the volcanic front of the Northeast Japan arc and the Izu-Ogasawara arc are different has already been discussed in terms of the difference between the modes of subduction of the two arcs (Notsu, 1983). The Northeast Japan arc and the Izu-Ogasawara arc are located adjacently

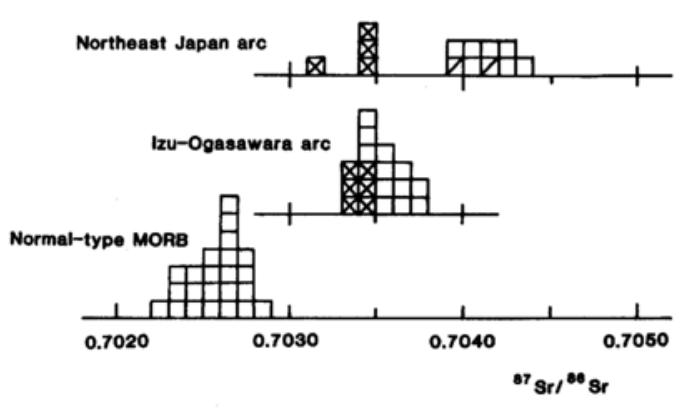

Fig. 5. Histograms of ${ }^{87} \mathrm{Sr} /{ }^{86} \mathrm{Sr}$ ratios in the IzuOgasawara arc, the Northeast Japan arc and normal-type MORB.

For both arcs $\square$ Volcanoes on the volcanic front

$\square$ Volcanoes near the volcanic front (NE Japan arc)

$\otimes$ Volcanoes behind the volcanic front For normal-type MORB, without detailed classification.

and the Pacific plate subducts beneath the Eurasia plate in the former arc and beneath the Philippine Sea plate in the latter arc, respectively. The dip angle of the Wadati-Benioff zone is steeper and the thickness of the crust over the mantle wedge is thinner in the IzuOgasawara arc than in the Northeast Japan arc. Considering that the subducted slab accompanied by oceanic sediments, altered basalt or sea water supplies a high ${ }^{87} \mathrm{Sr} /{ }^{86} \mathrm{Sr}$ component to the primary magma formed from the partially melted mantle wedge, we define these phenomena as the "interaction" between the subducting slab and the mantle wedge. As the "interaction" is more sensitive on the volcanic front side than on the back-arc side, we can characterize the Izu-Ogasawara arc and the Northeast Japan arc on the basis of the ${ }^{87} \mathrm{Sr} /{ }^{86} \mathrm{Sr}$ ratios on the volcanic front side. As the "interaction" is thought to become smaller away from the volcanic front, the lowest ratios approximate to the value of the mantle wedge for both the arcs. But, even in the volcanoes on the back-arc sides of both the arcs, the contribution of the subducting slab is not negligible because the ${ }^{87} \mathrm{Sr} /{ }^{86} \mathrm{Sr}$ ratios are slightly higher than those in the normal-type 
MORB.

\section{CONCLUSIONS}

(1) Rocks of the volcanic front of the IzuOgasawara arc have constant ${ }^{87} \mathrm{Sr} /{ }^{86} \mathrm{Sr}$ ratios (0.7034-0.7039), which are lower than those for the volcanoes on the volcanic front of the Northeast Japan arc $(0.7038-0.7045)$. The constancy of the ${ }^{87} \mathrm{Sr} /{ }^{86} \mathrm{Sr}$ ratios is confirmed for all the region of the Izu-Ogasawara arc, over $1,200 \mathrm{~km}$.

(2) Across-arc ${ }^{87} \mathrm{Sr} /{ }^{86} \mathrm{Sr}$ ratio variation is observed. The ratio decreases away from the volcanic front, as in the case of the Northeast Japan arc.

(3) The ${ }^{87} \mathrm{Sr} /{ }^{86} \mathrm{Sr}$ ratios of different volcanic rocks from one volcanic island concentrate within 0.0002 , regardless of the difference in the rock type and the eruptive stage. This suggests that, in each volcanic island, the magma is not subjected to contamination with different ${ }^{87} \mathrm{Sr} /{ }^{86} \mathrm{Sr}$ ratios during fractional crystallization.

Acknowledgements-We wish to thank Prof. NAOKI ONUMA for continuous discussion and for critical reading of the manuscript. Rock samples were donated by Dr. KANTARO FUJIOKA of Ocean Research Institute of the University of Tokyo (Ōmurodashi), Emeritus Prof. HIROSHI HAMAGUCHI of the University of Tokyo (Myōjin Reef), Prof. MASARU KoNO of Tokyo Institute of Technology (one sample of Nishinoshima), Prof. MAGOSHICHI SATO of Tokai University (Inambajima and one sample of Nishinoshima) and Mr. MAKOTO YUASA of the Geological Survey of Japan (Kurose Hole and Minami-iwōjima). We thank these persons. WDXRF facilities were provided by Geophysical Institute, the University of Tokyo, and ED-XRF by Rigaku Industrial Cooperation.

\section{REFERENCES}

DiXoN, T. H. and BATIZA, R. (1979) Petrology and chemistry of recent lavas in the northern Marianas: Implications for the origin of island arc basalts. Contrib. Mineral. Petrol. 70, 167-181.

FuJIMAKI, H. and KuRASAWA, H. (1980) Lateral variation of REE pattern of basaltic magma across the Japan arc. J. Japan Assoc. Min. Petr. Econ.
Geol. 75, 313-322.

Hamuro, K., ARAMaKi, S., Fujioka, K., Ishin, T., TANAKA, T. and UTO, K. (1983) The Higashi-Izuoki submarine volcanoes, part 2 , and the submarine volcanoes near the Izu Shoto Islands. Bull. Earthq. Res. Inst. 58, 527-557.

HaWkesworth, C. J., O'Nions, R. K., PANKhURST, R. J., HAMilton, P. J. and EVENSEN, N. M. (1977) A geochemical study of island-arc and back-arc tholeiites from the Scotia Sea. Earth Planet. Sci. Lett. 36, 253-262.

HEDGE, C. E. and KNIGHT, R. J. (1969) Lead and strontium isotopes in volcanic rocks from northern Honshu, Japan. Geochem. J. 3, 15-24.

HIRANO, M. (1982) Arc volcanism in Izu-Islands, Japan, based on $\mathrm{Sr} / \mathrm{Ca}-\mathrm{Ba} / \mathrm{Ca}$ diagram. Dr. Thesis (University of Tsukuba).

HIRANO, M., ISSHIKI, N. and ONUMA, N. (1982) Sr/ $\mathrm{Ca}-\mathrm{Ba} / \mathrm{Ca}$ systematics in Miyakejima, Ōnoharajima, Mikurajima and Inambajima volcanoes, the Izu Islands, Japan. Geochem. J. 16, 79-87.

HONZA, E., INOUE, E. and IsHiHARA, T. (eds) (1981) Geochemical investigation of the Ogasawara (Bonin) and northern Mariana arcs. April-August 1979 (GH79-2, 3 and 4 cruises). Cruise Report No. 14. Geol. Surv. Japan, 170p.

ISSHIKI, N. (1955) Ao-ga-sima volcano. Japan J. Geol. Geogr. 26, 209-218.

ISSHIKI, N. (1959) The geological sheet map "Hachijö-jima", scale 1:50,000, and its explanatory text. Geol. Surv. Japan, 58p. (in Japanese with English abstract).

ISSHIKI, N. (1960) The geological sheet map "Miyakejima", scale 1:50,000, and its explanatory text. Geol. Surv. Japan, 85p. (in Japanese with English abstract).

ISSHIKI, N. (1963) Petrology of Hachijō-jima Volcano Group, Seven Izu Islands, Japan. J. Fac. Sci. Univ. Tokyo, Sec. II 15, 91-134.

IssHIKI, N. (1964) $\bar{O}$-shima volcano. Guidebook for excursion 2. Geol. Surv. Japan, 24p.

ISSHIKI, N. (1976) Geology and petrography of Iwo-jima (Sulphur Island), Volcano Islands. Research Notes of the National Research Center for Disaster Prevention 23, 5-16 (in Japanese with English abstract).

IsSHIKI, N. (1978) Geology of the Toshima district. Quadrangle Series, scale 1:50,000, Geol. Surv. Japan, 34p. (in Japanese with English abstract).

ISSHIKI, N. (1980) Geology of the Mikurajima, Inambajima and Zenisu districts. Quadrangle Series, scale 1:50,000, Geol. Surv. Japan, 35p. (in Japanese with English abstract).

ISSHIKI, N. (1982) Geology of the Kõzushima district. 
Quadrangle Series, 1 : 50,000, Geol. Surv. Japan, 75p. (in Japanese with English abstract).

ISSHIKI, N., ONUMA, N. and HIRANO, M. (1982)

$\mathrm{Sr} / \mathrm{Ca}-\mathrm{Ba} / \mathrm{Ca}$ systematics of Quaternary volcanoes in Toshima, Udonejima, Niijima and Kōzushima, the Izu Islands, Japan. Geochem. J. 16, 119-127.

KATSURA, T. and NAKAMURA, K. (1960) Chemical composition of younger volcanic rocks of Ōshima volcano, Izu. Kazan, Ser. II 5, 75-98 (in Japanese with English abstract).

KAWADA, G. (1962) Table of chemical analyses by Geological Survey of Japan I (Rocks and minerals, 1954-1960). Rept. Geol. Surv. Japan, no. 195, $176 \mathrm{p}$.

KUnO, H. ed. (1962) Catalogue of the active volcanoes of the world including solfatara fields. Part XI Japan, Taiwan and Marianas. International Association of Volcanology, Roma, 332p.

KURASAWA, H. (1979) Isotopic composition of strontium in volcanic rocks from Fuji, Hakone and Izu area, central Japan. Kazan, Ser. II 24, 135-152 (in Japanese with English abstract).

MASUDA, A. (1968) Geochemistry of lanthanides in basalts of central Japan. Earth Planet. Sci. Lett. 4, 282-292.

MATSUDA, J., ZASHU, S. and OZIMA, M. (1977) Sr isotopic studies of volcanic rocks from island arcs in the western Pacific. Tectonophysics 37, 141-151.

MATSUHISA, Y. (1979) Oxygen isotopic compositions of volcanic rocks from the East Japan island arcs and their bearing on petrogenesis. J. Volcanol. Geotherm. Res. 5, 271-296.

MEIJER, A. (1976) $\mathrm{Pb}$ and $\mathrm{Sr}$ isotopic data bearing on the origin of volcanic rocks from the Mariana island-arc system. Geol. Soc. Am. Bull. 87, 13581369.

NOHDA, S. and WASSERBURG, G. J. (1981) Nd and $\mathrm{Sr}$ isotopic study of volcanic rocks from Japan. Earth Planet. Sci. Lett. 52, 264-276.

NoTSU, K. (1983) Strontium isotope composition in volcanic rocks from the Northeast Japan arc. J. Volcanol. Geotherm. Res. 18, 531-548.

ONUMA, N., HIRANO, M. and ISSHIKI, N. (1981) Sr/ $\mathrm{Ca}-\mathrm{Ba} / \mathrm{Ca}$ systematics in four volcanoes of Ōshima, Izu Islands, Japan. Geochem. J. 15, 315-324.

ONUMA, N., HIRANO, M. and ISSHIKI, N. (1983)

Genesis of basalt magmas and their derivatives under the Izu Islands, Japan, inferred from $\mathrm{Sr} / \mathrm{Ca}-\mathrm{Ba} / \mathrm{Ca}$ systematics. J. Volcanol. Geotherm. Res. 18, 511529.

OSSAKA, J., ŌHIRA, Y. and MINATO, I. (1974) On the submarine eruption of Nishinoshima (3). Kazan, Ser. II 19, 37-38 (in Japanese with English abstract).
PUSHKAR, P. (1968) Strontium isotope ratios in volcanic rocks of three island arc areas. J. Geophys. Res. 73, 2701-2714.

STERN, R. J. (1982) Strontium isotopes from circumPacific intra-oceanic island arcs and marginal basins: Regional variations and implications for magma genesis. Geol. Soc. Am. Bull. 93, 477-486.

Sun, S. -S., NeSBITT, R. W. and Sharaskin, A. Y. (1979) Geochemical characteristics of mid-ocean ridge basalts. Earth Planet. Sci. Lett. 44, 119-138.

SuWA, A. (1953) Submarine eruption of Myojin Reef. J. Geogr. 62, 100-110 (in Japanese with English abstract).

TAYLOR, H. P., JR. (1980) The effects of assimilation of country rocks by magmas on ${ }^{18} 0 /{ }^{16} 0$. and ${ }^{87} \mathrm{Sr} /$ ${ }^{86} \mathrm{Sr}$ systematics in igneous rocks. Earth Planet. Sci. Lett. 47, 243-254.

YUASA, M. and TAMAKI, K. (1982) Basalt from Minami-Iwojima Island, Volcano Islands. Bull. Geol. Surv. Japan 33, 531-540 (in Japanese with English abstract).

WHITFORD, D. J. (1975) Strontium isotopic studies of the volcanic rocks of the Sunda arc, Indonesia, and their petrogenetic implications. Geochim. Cosmochim. Acta 39, 1287-1302.

\section{APPENDIX}

Sample localities and references

Ōshima volcano

1. Okata volcano

56091919 A welded spatter exposed on the sea-cliff at Kazahayazaki on the northern coast. No. 148 in KAWADA (1962). No. 2, Table 1 in ISSHIKI (1964).

56091908 The middle part of a composite lava flow exposed on the sea-cliff at Kazahayazaki on the northern coast.

2. Fudeshima volcano

NI60030903a A dike exposed on the sea-cliff opposite to Fudeshima Rock on the eastern coast. No. 7, Table 1 in ISSHIKI (1964).

3. Gyōjanoiwaya volcano

NI60030101 The lowermost lava flow exposed at Gyōjanoiwaya on the eastern coast. No. 187 in KaWAdA (1962). No. 8, Table 1 in ISSHIKI (1964).

4. Ōshima volcano

4.1 Older unit of pre-caldera stratovolcano

56102301 A lava flow exposed on the sea-cliff opposite to Naenone Rock on the 
northern coast. No. 188 in KAWADA (1962). No. 1, Table 2 in ISSHIKI (1964).

4.2 Younger unit of pre-caldera stratovolcano

NI60030403 A lava flow exposed at the head of the Funōnotaki falls on the eastern coast. No. 149 in KAWADA (1962). No. 6, Table 2 in ISSHIKI (1964).

NI60030407 A lava flow exposed at the head of the Funonotaki falls on the eastern coast. No. 189 in KAWADA (1962). No. 3, Table 2 in ISSHIKI (1964).

4.3 Post-caldera scoria cones and lava flows

NI59111901 Lava flow of $\mathrm{Y}_{5}(1338$ ?) exposed at Naganemisaki on the western coast. No. 683, Table 5 in KATSURA and NAKAMURA (1960).

NI59090702 Welded spatter of $Y_{1}(1777-1778)$ exposed on the northwestern flank of Miharayama. No. 190 in KAWADA (1962).

NI59021201 Lava flow of March, 1951 exposed $1 \mathrm{~km}$ to the northeast of Miharayama crater. No. 191 in KAWADA (1962).

Ōmurodashi $\left(34^{\circ} 32^{\prime} \mathrm{N}, 139^{\circ} 29^{\circ} \mathrm{E}\right)$

KT79-18, 118-002

Rock fragment dredged from a depression about $1 \mathrm{~km}$ long from the northwest to the southeast, about $500 \mathrm{~m}$ wide and about $100 \mathrm{~m}$ deep KT79-18, 118-004 on the bank (HAMURO et al., 1983).

Toshima

The same location as $118-002$.

NI70053001 The lowermost lava flow near Nazukata on the eastern coast. No. 1, Table 1 in ISSHIKI (1978).

NI70052903 A lava flow exposed on the sea-cliff near Ōne on the northwestern coast. No. 2, Table 1 in ISSHIKI (1978).

NI70060606 A lava flow exposed on the sea-cliff a little west of a landing place at Maehama on the northern coast. No. 3, Table 1 in ISSHIKI (1978).

Udonejima

NI70053101 A dike exposed at the east-southeastern tip.

NI70053109 A dike exposed at the west-northwestern tip.

Niijima

1. Jinaijima volcano

NI73052505 Dome lava exposed at Kirema of Jinaijima.
2. Shimawakezawa pyroclastic rock

NI73030307 Essential lapilli exposed on the right bank of Shimawakezawa on the western coast.

3. Miyatsukayama volcano

NI73030607a Doma lava exposed on the eastern wall of Miyatsukayama in the middle of Niijima.

4. Wakagō volcano

NI71053103 A bomb in the pyroclastic surge deposit exposed at the northern end of Wakagō-Maehama.

5. Mukaiyama volcano

NI71061203 Dome lava exposed on a roadcut east of Tangoyama.

Kōzushima

1. Membō volcano

NI60072504 A cognate inclusion in dome lava exposed on the sea-cliff near the Közushima lighthouse at the southwestern tip. No. 4, Table 4 in ISSHIKI (1982).

NI60072503 Dome lava exposed on the sea-cliff near the Kōzushima lighthouse at the southwestern tip.

2. Nagahama volcano

NI76053102 A lava flow exposed at the northern end of Maehama.

3. Sanukayama volcano

NI60072102 Lithic part of dome lava exposed at the east-northeastern end of Takō Bay. No. 7, Table 4 in ISSHIKI (1982).

4. Tenjōsan volcano

NI60072406 Dome lava exposed near a trail about $300 \mathrm{~m}$ north of Fudōson on Tenjōsan.

Miyakejima

NI57073001 A lava flow exposed on the sea-cliff about $700 \mathrm{~m}$ north of Ako on the western coast. No. 1, Table 2 in ISSHIKI (1960).

NI74112701 A bomb exposed on a roadcut about $100 \mathrm{~m}$ north of Naganehachiman on the western foot.

NI57080611b The middle part of composite lava flow of 1874 exposed between Kamitsuki and Tosa on the northern foot. No. 8, Table 2 in IsSHIKI (1960).

NI62090902 Lava flow of August, 1962 on the northeastern flank.

Ōnoharajima

NI57072505 A cognate inclusion in dome lava exposed at $\bar{O}$ ne.

NI57072504 Dome lava exposed at Ōne. No. 11, 
Table 2 in IsSHIKI (1960).

Mikurajima

1. Main stratovolcano

NI60091401 A lava flow exposed on the sea-cliff north of Uranne on the western coast. No. 2, Table 1 in ISSHIKI (1980).

NI60092406 A float of welded spatter found about $1 \mathrm{~km}$ north of Oyama. No. 4, Table 1 in ISSHIKI (1980).

2. Lava dome group

NI60091805 Dome lava of Yasukajigamori about $1.2 \mathrm{~km}$ southwest of Nangō. No. 7, Table 1 in ISSHIKI (1980).

Inambajima

NI62060801c Dome lava exposed at the northeastern tip.

Kurose Hole

GH79-4-RC63 A pumice block collected by a rock corer at $33^{\circ} 23.1^{\prime} \mathrm{N}$ and $139^{\circ} 41.0^{\prime} \mathrm{E}$, and $630 \mathrm{~m}$ deep from the floor of a "caldera" about $7 \mathrm{~km}$ wide and about $500 \mathrm{~m}$ deep (HonZA et al., 1981).

Hachijōjima

1. Basement rock

NI55071806 An accidental block in pumice tuff of pre-caldera stratovolcano of Higashiyama volcano exposed on the seacliff on the southeastern coast.

2. Yokomagaura volcano

$\mathrm{NOHO2} \mathrm{A} \mathrm{lava} \mathrm{flow} \mathrm{exposed} \mathrm{on} \mathrm{a} \mathrm{roadcut} \mathrm{of}$ Yokomagaura on the western coast. The same locality as NI52092612 (No. 2, Table 2 in ISSHIKI (1959)).

3. Higashiyama volcano

3.1 Pre-caldera stratovolcano

NI54071401 A dike possibly related to the precaldera stratovolcano which is exposed at the southern end of Yokomagaura on the western coast. No. 5, Table 2 in ISSHIKI (1959).

NI54072007 A dike possibly related to the precaldera stratovolcano which is exposed on the sea-cliff south of Yokomagaura on the western coast. No. 6, Table 2 in ISSHIKI (1959).

NI52101709 A lava flow exposed on the sea-cliff on the eastern coast. No. 7, Table 2 in ISSHIKI (1959).

NI57032205(2) A bread-crust bomb in a pumice flow deposit exposed on a roadcut of Yokomagaura on the western coast. No. 8, Table 2 in ISSHIKI (1959).
NI53011301 A float of obsidian found on the northwestern flank. No. 9, Table 2 in ISSHIKI (1959).

3.2 Post-caldera stratovolcano

NI52101202 A lava flow exposed on the stream-bed of Karatakigawa on the southern foot. No. 13, Table 2 in ISSHIKI (1959).

NI54071706 A lava flow exposed on the sea-cliff on the southwestern coast. No. 12, Table 2 in ISSHIKI (1959).

NI54073103 A lava flow exposed on the left bank of $\overline{\text { Okawa about }} 0.9 \mathrm{~km}$ north-northeast of the summit of Higashiyama. No. 14, Table 2 in ISSHIKI (1959).

NI52092601 A lava flow exposed on a roadcut at the northern end of Yokomagaura on the western coast. No. 4, Table 2 in ISSHIKI (1959).

NI54071101 A lava flow exposed on the west face of the $220 \mathrm{~m}$-high peak about $0.4 \mathrm{~km}$ south-southeast of Ōsato on the western foot. No. 3, Table 11 in ISSHIKI (1963).

4. Nishiyama volcano

NI55072003 A lava fill exposed on the southwestern wall of the pit within the summit crater. No. 20, Table 2 in ISSHIKI (1959).

NI53072705 A lava flow exposed at NambaraSenjojiki on the south-southwestern foot. No. 22, Table 2 in ISSHIKI (1959).

Aogashima

NI53081111 A lava flow (or a dike) exposed at a middle horizon of the sea-cliff of Mikonoura on the northern coast. No. 2, Table 1 in ISSHIKI (1955).

NI53081102 A lava flow exposed at an upper horizon of the sea-cliff of Mikonoura on the northern coast. No. 3, Table 1 in ISSHIKI (1955).

NI53081105 The northern front of a central cone lava flow exposed within the summit crater of the main stratovolcano. No. 5, Table 1 in ISSHIKI (1955).

Myōjin Reef Pumice

A pumice block collected by $\mathrm{H}$. HAMAGUCHI on the deck of S.S. Shinyo Maru near Myōjin Reef on Sep. 23, 1952 during the submarine eruption. No. I, Table 3 in SUWA (1953).

Torishima

NI56101805 A dike related to the main strato- 
volcano, exposed on the sea-cliff near Nagane on the southwestern coast. No. 1, Table 47 in KUNO (1962).

NI56101509 A scoriaceous fragment in the scoria fall deposit exposed near Tamaokisato at the northwestern foot. No. 2, Table 47 in KunO (1962).

NI56102108 A central cone lava flow exposed on the eastern wall of the former Hyōgo Bay on the northern coast. No. 4, Table 47 in Kuno (1962).

NI56102003 A central cone lava flow exposed at Tsubamezaki on the southern coast. No. 6, Table 47 in Kuno (1962).

NI56102103 A bomb of central cone Komochiyama. No. 5, Table 47 in KuNO (1962).

NI56102102 A cognate inclusion in a bomb of the central cone, Komochiyama.

NI56101702 Lava flow of 1939 exposed at Chitoseura on the northern coast. No. 7, Table 47 in KuNO (1962).

Nishinoshima

NI74071802 A lava flow exposed on the eastern coast of the older island.
B

Scoria block collected by M. KoNO from the scoria cone on the western coast of the new island on March 10, 1974. Sample B, Table 6 in OSSAKA et al. (1974).

Iwōjima (Geology and petrography are described in ISSHIKI (1976).)

NI68082304 A lava flow exposed on the eastern coast of Motoyama forming the northeastern part of the island.

NI68082301b A plutonic cognate inclusion in agglomerate exposed on the eastern coast of Motoyama forming the northeastern part of the island.

NI68082503 A lava flow which is covered by Suribachiyama scoria cone at the southwestern tip of the island.

Minami-iwōjima

79043001 A dike exposed on the northern coast. Table 4 in YUASA and TAMAKI (1982).

79043002 A lava flow exposed on the northern coast. Table 4 in YUASA and TAMAKI (1982). 